\title{
Edukasi perilaku sehat untuk meningkatkan imunitas dalam menghadapi pandemi Covid-19 di SMA Negeri 2 Bandar Lampung
}

\author{
Khairun Nisa Berawi ${ }^{1,2^{*}}$, TA Larasati ${ }^{1}$, Dewi Nur Fiana ${ }^{1}$, Roro Rukmi Windi Perdami ${ }^{1}$, \\ Dewi Ayu Puspaningrum ${ }^{2}$
}

1Program Studi Pendidikan Dokter Fakultas Kedokteran, Universitas Lampung

2Pasca Sarjana Magister Ilmu Lingkungan, Universitas Lampung

e-mail: khairun.nisa@fk.unila.ac.id

\begin{abstract}
Abstrak
Bandar Lampung termasuk daerah dengan prevalensi Covid-19 tertinggi di Provinsi Lampung dengan total kematian sampai bulan September 2020 mencapai 15 pasien. Penyakit ini rentan menyerang remaja sekolah karena kelompok remaja menjadi komunitas yang banyak beraktifitas di luar rumah sehingga berisiko terpapar Covid-19. Remaja biasanya terinfeksi dengan status tanpa gejala sehingga berisiko menularkan. SMAN 2 Bandar lampung merupakan sekolah favorit dan diharapkan pengabdian kepada masyarakat (PKM) ini akan membentuk komunitas remaja yang bisa menjadi model pelaku protokol Covid-19. Kegiatan PKM ini bertujuan meningkatkan imunitas atau status kesehatan pada kelompok remaja target melalui edukasi untuk menerapkan protokol Covid-19 untuk membangun perilaku sehat sebagai upaya pencegahan Covid-19. Metode PKM menggunakan teknik penyuluhan serta demonstrasi video dan edukasi yang menunjukkan beberapa hal mengenai covid-19 dan pencegahannya, aturan menjaga jarak, cuci tangan dan masker yang dipresentasikan melalui daring, buku saku dan pamflet sebagai wahana edukasi berkelanjutan. Proses kegiatan yang dilaksanakan didapatkan peningkatan pengetahuan berdasarkan nilai rata-rata post-test sebesar 83, sedangkan nilai pre-test hanya sebesar 65. Diharapkan para siswa dapat mengimplikasikan pengetahuan dan pemahaman yang didapat mengenai protokol Covid-19 dan pencegahannya pada diri sendiri dan lingkungan sekitarnya.
\end{abstract}

Kata Kunci : Edukasi Perilaku Sehat, Imunitas, Covid-19, Remaja

\begin{abstract}
Promoting healthy behaviors to increase immunity in facing the covid-19 pandemic at SMA Negeri 2 Bandar Lampung. Bandar Lampung is one of the areas with the highest Covid-19 prevalence in Lampung Province with total deaths up to September 2020 reaching 15 patients. This disease is vulnerable to attacking school adolescents because youth groups become a community that has a lot of activities outside the home so that they are at risk of being exposed to Covid-19. Adolescents are usually infected with no symptoms so that they are at risk of transmitting. SMAN 2 Bandar Lampung is a favorite school and it is hoped that this community service (PKM) will form a youth community who can become a model for the Covid-19 protocol actors. This activity aimed to increase immunity or health status in target youth groups through education to apply the Covid-19 protocol to build healthy behavior as an effort to prevent Covid-19. The method used counseling techniques as well as video and educational demonstrations that show several things about Covid-19 and its prevention, social/ physical distancing, hand washing and masks presented online, pocket book and pamphlets as mean of continuous education. The process of activities carried out obtained an increase in
\end{abstract}


knowledge based on the average post-test score of 83, while the pre-test score was only 65. It is hoped that students will be able to imply the knowledge and understanding they have gained regarding the Covid-19 protocol and its prevention in themselves and their surroundings.

Keywords : Promoting Healthy Behaviors, Immunity, Covid-19, Adolescents

\section{PENDAHULUAN}

Penyakit Covid-19 merupakan penyakit infeksi saluran nafas akut berat yang disebabkan oleh virus Severe Acute Respiratory Syndrome Coronavirus-2 (SARS-CoV-2). Penyakit ini pertama kali didapatkan di Kota Wuhan, Cina pada Bulan Desember 2019. Covid-19 awalnya diduga ditularkan dari hewan ke manusia dan pada perkembangan terbukti dapat menular dari manusia ke manusia melalui percikan batuk/ bersin bahkan bicara (droplet) dan udara (airborne). Lingkungan Rumah Sakit (RS) di ruangan tindakan ke saluran nafas seperti intubasi dan nebulizer ditemukan dapat memicu terjadinya aerosolisasi udara yang meningkatkan konsentrasi partikel virus diudara. Virus ini dapat bertahan sampai 3 jam dan meningkatkan risiko infeksi pada orang yang berada di ruangan tersebut. Oleh karena itu, tenaga kesehatan menjadi bagian dari kelompok rentan infeksi. ${ }^{1,2,3,4,5}$

Penularan penyakit Covid-19 pada masyarakat menjadi masalah kesehatan yang perlu diwaspadai di Provinsi Lampung. Dinas Kesehatan Provinsi Lampung menyatakan bahwa Provinsi Lampung mengalami lonjakan tinggi kasus Covid-19 dalam sehari pada tanggal 17 September 2020, yang mencapai 21 pasien baru. Berdasarkan data yang telah dikumpulkan, Bandar Lampung adalah kota dengan prevalensi tertinggi di Provinsi Lampung setelah Kabupaten Lampung Barat, Kabupaten Lampung Utara, Kabupaten Lampung Tengah, Kabupaten Lampung Selatan, dengan penambahan sebanyak 9 kasus baru. Hal ini terlihat pada laman peta sebaran Dinas Kesehatan Provinsi Lampung pada tanggal yang sama, Bandar Lampung memiliki prevalensi kasus Covid-19 tertinggi dengan total konfirmasi mencapai 254 pasien dengan total kematian mencapai 15 pasien. Kondisi ini memicu kekhawatiran sendiri yang membutuhkan solusi untuk diselesaikan. 
Peningkatan status red zone dengan adanya kasus transmisi lokal, memerlukan kerjasama dari banyak pihak untuk membangun kesadaran masyarakat khususnya di kalangan remaja di Bandar Lampung untuk ikut berperan mencegah penyebaran Covid-19 ini. Penerapan perilaku hidup sehat harus dilakukan oleh seluruh lapisan masyarakat termasuk kelompok remaja untuk mencegah Covid-19 dan penyebarannya.6,7,8,9

Kelompok remaja di sekolah merupakan kelompok rentan terpapar Covid-19 dengan status OTG (orang tanpa gejala). ${ }^{9}$ Oleh karena itu, perlunya respon untuk mencegah penyebaran Covid-19 dengan pemberian edukasi perilaku sehat untuk meningkatkan imunitas remaja dalam menghadapi pandemi Covid-19. Pelaksanaan kegiatan ini bertempat di SMA Negeri 2 Bandar Lampung. Kegiatan ini diharapkan meningkatkan perilaku yang lebih sehat dalam upaya pencegahan Covid-19 di kalangan remaja.

\section{TINJAUAN PUSTAKA}

Penyakit ini ditularkan melalui manusia ke manusia dimana sebagian besar orang yang terinfeksi (COVID-19) akan mengalami penyakit pernapasan ringan hingga sedang dan sembuh tanpa memerlukan perawatan khusus. Pada penderita usia lanjut dan memiliki masalah kesehatan lain seperti penyakit kardiovaskular, diabetes, penyakit pernapasan kronis, dan kanker, dapat memperberat penyakit tersebut. Cara terbaik untuk mencegah dan memperlambat penularan adalah dengan edukasi tentang COVID-19, pola hidup sehat dan melakukan kebersihan tangan secara benar. Berdasarkan berbagai penelitian ilmiah, COVID-19 ditularkan melalui droplet, kontaminasi permukaan, dan aerosol sehingga sangat berisiko pada orang yang melakukan kontak rapat. ${ }^{10,11,12,13}$

Hasil riset menunjukkan adanya kelompok rentan yang potensial untuk terinfeksi dan pada perjalanan penyakitnya dapat berkembang menjadi berat bahkan kematian. Kelompok rentan ini termasuk pria usia diatas 55 tahun atau lanjut usia, orang dengan penyakit komorbid seperti diabetes melitus, hipertensi dan penyakit jantung. Remaja menjadi menjadi kelompok yang bisa terinfeksi tapi tanpa gejala atau dikenal orang tanpa 
gejala (OTG). Hal ini menyebabkan remaja harus semakin ditingkatkan kesadaran dan peningkatan perilaku sehatnya dalam upaya mencegah mereka terinfeksi maupun menginfeksi kepada yang lain khususnya kelompok rentan. 2, 9,14,15,16

\section{METODE}

Pelaksanaan kegiatan pengabdian kepada masyarakat (PKM) oleh tim PKM dilakukan pada bulan 8 Desember 2020 secara online (daring) di Laboratorium Fisiologi, Biomolekuler dan Biokimia FK UNILA secara daring dengan peserta para siswa SMA Negeri 2 Bandar Lampung. Kegiatan menggunakan metode penyuluhan serta demonstrasi video yang menunjukkan beberapa hal mengenai social/ physical distancing, cuci tangan dan masker yang dipresentasikan pada kelompok target melalui daring, serta dihasilkannya buku saku dan pamflet untuk ditempelkan ke papan pengumuman sekolah sebagai wahana edukasi yang terus menerus bagi semua siswa dan siswinya. Kegiatan di evaluasi dengan pemberian pre-test dan post-test juga produk yang dihasilkan untuk keberlanjutan PKM.

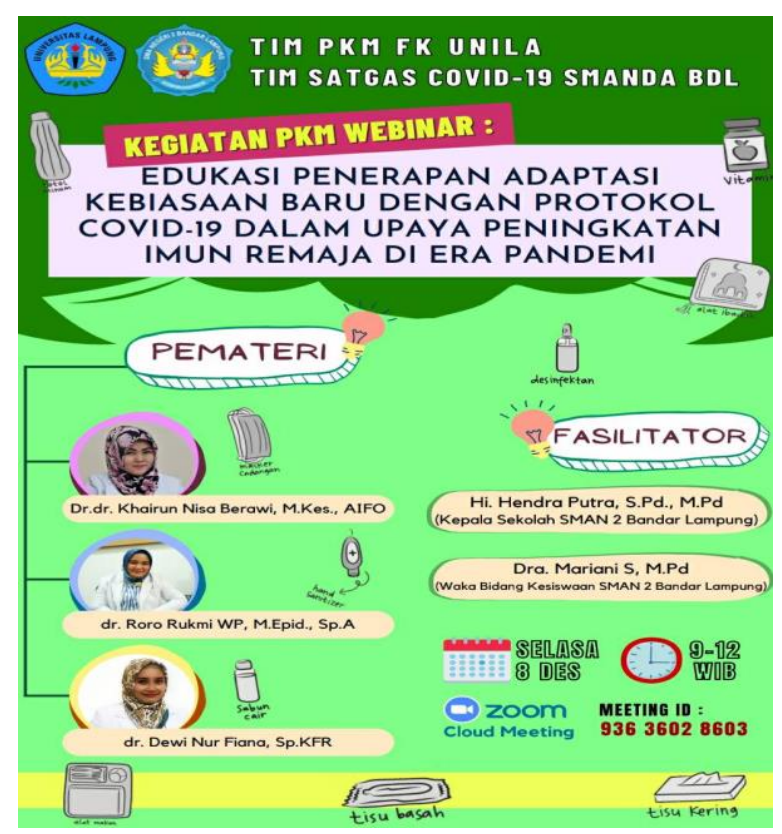

Gambar 1. Flyer PKM online

\section{HASIL DAN PEMBAHASAN}


Pengabdian kepada masyarakat ini diharapkan membantu pemerintah dalam upaya mencegah penularan Covid-19 di Bandar Lampung. PKM dilaksanakan di SMA Negeri 2 Bandar Lampung dengan mengadakan kegiatan webinar yang dilaksanakan tanggal 8 Desember 2020 pukul 09.00 WIB sampai pukul 12.00 WIB dengan diikuti 300 peserta yang terdiri dari 285 siswa siswi SMA Negeri 2 Bandar Lampung, 5 orang guru dan pimpinan sekolah dan 10 orang panitia pelaksana dari tim PKM Unila dan SMA Negeri 2 Bandar Lampung.

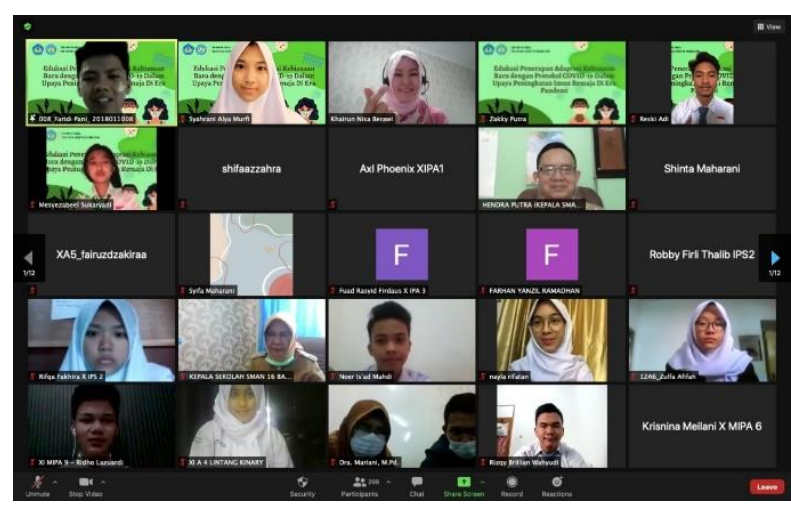

Gambar 2. Peserta kegiatan PKM

Peserta terlebih dahulu mengisi daftar hadir, yang kemudian dilanjutkan dengan pemberian pretest dan posttest guna mengevaluasi capaian dan tingkat pemahaman perilaku yang akan di adopsi dari pelatihan. Kegiatan penyuluhan yang disampaikan oleh narasumber, dimana termuat empat materi utama yaitu: Mengenal Covid-19 dan Metode Penularannya, Edukasi Perilaku Sehat untuk Meningkatkan Imunitas, Edukasi Penggunaan Masker yang Benar, Edukasi Mengelola Social E Personal Distancing untuk Mencegah Covid19.

Evaluasi dari pemahaman pelajar peserta edukasi mengenai Perilaku Sehat (Pola Hidup Bersih dan Sehat) dan mengadopsi Perilaku Proteksi dalam mencegah penularan Covid-19. Hasil nilai rata-rata pretest peserta kegiatan ini 65 dan rata-rata posttest 83, mengindikasikan adanya peningkatan pengetahuan yang diharapkan meningkatkan kesadaran perubahan perilaku penerapan protokol Covid-19 dalam upaya pencegahan 
penyebaran Covid-19. Untuk keberlanjutan proses edukasi tim PKM telah menyusun buku saku dan leaflet yang dibagikan ke pihak sekolah sebagai wahana edukasi berkelanjutan bagi peserta dan seluruh civitas SMA N 2 Bandar Lampung.

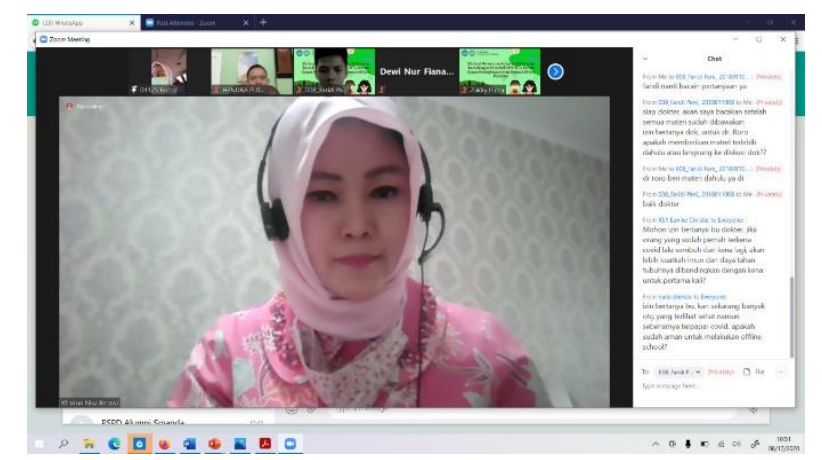

Gambar 3. Pemaparan materi dan diskusi oleh narasumber

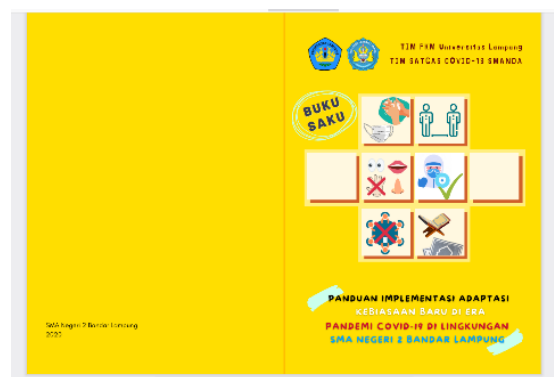

Gambar 4. Buku Saku Panduan Implementasi AKB di Era Pandemi Covid-19 SMAN 2 Bandar Lampung

Pemaparan materi secara lebih rinci dimaksudkan untuk pencegahan penyebaran Covid-19 merupakan hal penting dalam upaya menekan angka kejadian Covid-19. Upaya pencegahan penyebaran dengan kegiatan yang multisektoral dengan kombinasi langkahlangkah kesehatan masyarakat, seperti identifikasi cepat, diagnosis dan pengelolaan kasus, identifikasi dan tindak lanjut dari kontak, pencegahan infeksi dan kontrol dalam pengaturan layanan kesehatan, penerapan langkah-langkah kesehatan untuk pelancong, peningkatan kesadaran dalam populasi dan komunikasi risiko, diharapkan membantu penyebaran covid-19. Metode pemberdayaan masyarakat termasuk dengan melibatkan komunitas remaja akan menjadi solusi yang baik dalam upaya peningkatan kesadaran 
masyarakat. Komunitas remaja yang aktif dan banyak beraktifitas di luar rumah dengan komunitasnya, menjadi target potensial yang dapat dilibatkan dalam beberapa upaya peningkatan kesadaran masyarakat untuk mencegah penyebaran Covid 19.1,7,4 PKM ini diharapkan akan menjadi wahana edukasi berkelanjutan dengan dukungan buku saku dan pamflet yang sudah dibuat bagi para peserta khususnya dan masyarakat secara umum.

Penyampaian materi diakhiri dengan membandingkan jumlah peserta yang hadir dengan jumlah yang mengikuti sampai akhir sesi dari 300 peserta dan diakhir sesi sebanyak 258 peserta juga tanya jawab yang berupa penyampaian pertanyaan oleh peserta sebanyak 34 orang baik secara langsung maupun melalui chat room. Selanjutnya, setelah sesi tanya jawab berakhir kami melakukan kegiatan evaluasi akhir dengan memberikan post-test kepada peserta yang berisi pertanyaan-pertanyaan yang sama dengan pre-test. Pada saat pre-test nilai rata-rata peserta adalah 65 , saat post-test nilai rata-rata peserta 83 . Peningkatan pengetahuan peserta diharapkan mengindikasikan peningkatan pengetahuan peserta kegiatan ini dan kesadaran perilaku sehat di era pandemi Covid-19.

\section{SIMPULAN}

Hasil pelaksanaan PKM mendapatkan adanya peningkatan pengetahuan dan para peserta kegiatan. Selanjutnya diharapkan dapat turut meningkatkan perilaku sehat dan penerapan Protokol Covid-19 yang tepat dalam upaya pencegahan penyebaran Covid-19.

\section{Referensi}

1. World Health Organization. Home care for patients with suspected novel coronavirus ( $\mathrm{nCoV}$ ) infection presenting with mild symptoms and management of contacts 2020.

2. Han Y, Yang H. The transmission and diagnosis of 2019 covel Coronavirus Infection Disease (COVID-19): a Chinese perspective. J Med Virol. 2020;92(6):639-44.

3. Wuhan Municipal Health Commission. Report of clustering pneumonia of unknown etiology in Wuhan City [in Chinese] 2020.

4. Wu Z, McGoogan J. Charateristics of and important lesson from the coronavirus disease 2019 (COVID-19) outbreak in China. JAMA - J Am Med Assoc. 2020;323(13): 1239-1242.

5. Kutter JS, Spronken MI, Fraaij PL, Fouchier RA, Herfst S. Transmission routes of respiratory viruses among humans. Curr Opin Virol. 2018;28:142-51. 
6. Jakarsih I. Peta Sebaran Corona di Lampung 17 September, Kasus Baru di 7 Daerah. Lampung77 [Internet]. 2020; Available from: https://www.lampung77.com/petasebaran-corona-di-lampung-17-september-kasus-baru-di-7-daerah/

7. Kementerian Kesehatan RI. Pedoman kesiapsiagaan menghadapi coronavirus disease (COVID-19) revisi ke-3.

8. Kementerian Kesehatan RI. Infeksi emerging. Kementrian Kesehatan RI [Internet]. 2020. Available from: http://infeksiemerging.kemkes.go.id/

9. Rothe C, Schunk M, Sothmann P. et al. Transmission of 2019-nCoV infection from an asymptomatic contact in Germany. N Engl J Med. 2020;382(10):970-1.

10. Department of Health and Social Care (DHSC), Public Health Wales (PHW), Public Health Agency (PHA) Northern Ireland HPS (HPS) and PHE as official guidance. COVID-19: Guidance for infection prevention and control in healthcare settings [Internet]. Vol. Version $1.2020 . \quad$ Available from: https://www.gov.uk/government/publications/wuhan-novel-coronavirus-infectionprevention-and-control

11. Van Dormalen N, Bushmaker T, Morris DH, et al. Aerosol and surface stability of SARSCoV-2 as compared with SARS-CoV-1. N Engl J Med. 2020; 382(16):1564-7.

12. Huang C, Wang Y, Li X, et al. Clinical features of patients infected with 2019 novel coronavirus in Wuhan, China. Lancet. 2020;395:497-506.

13. Zou L, Ruan F, Huang M, et al. SARS-CoV-2 viral load in upper respiratory specimens of infected patients. N Engl J Med. 2020;382:1177-9.

14. Bai $Y$, Yao L, Wei T, et al. Presumed asymptomatic carrier transmission of COVID-19. JAMA - J Am Med Assoc. 2020;323(14):1406-7.

15. Susilo A, Rumende CM, Pitoyo CW, et al. Coronavirus Disease 2019: Tinjauan Literatur Terkini. J Penyakit Dalam Indones. 2020;7(1):45.

16. Phan LT, Nguyen TV, Luong QC, et al. Importation and human-tohuman transmission of a novel coronavirus in Vietnam. N Engl J Med. 2020;382(9):872-4. 